\title{
Post-War Counseling for “'Tween Age” Youth
}

\author{
HOWARD Y. MCCLUSKY \\ University of Michigan
}

W

AR OR No war, youth keep on growing. Year by year they move up the chronological ladder into whatever status society has to offer them. An unending streamthey are the link of the present with the future.

For almost four years we have been absorbed with the job of war. Young people, especially the male half of the tribe, have been swallowed up by the Armed Servicesand adults have been pinned down by war production and other home-front duties. But now that the war is over we can try the wings of prophecy and take a fly at the future. Already attempts at post-war forecasts are legion; this is inevitable and proper, especially if we do not mistake speculation for certainty. We project plans about the returning veteran, and we should; and we try to anticipate the occupational fate of displaced war workers, and we should. But there is another group which, in the welter of speculation, we are likely to overlook, namely the youth, too young for the Armed Services, the "'tween age," who will come onto the labor market at a time of terrific competition.

For several reasons we know that the competition will be keen. In the first place, we should remind ourselves of the trend, underway for many years, which has made gainful employment for young people between the ages of 16 and 25 increasingly diffcult. Those persons familiar with developments in the fields of child labor legislation, workmen's compensation, and employment practices will confirm this point. In fact, one of the outstanding features of the occupational market before the fall of France in 1940 , a feature of which we can never be too often reminded, was that young people between the ages of 16 and 25 were carrying a disproportionate share of the unemployment prevalent in the country. In order to refresh our memory, let us review some data from the 1937 Census of Unemployment. According to this inventory, one third of the unemployed workers in the United States were young people between 15 and 24 years of age, inclusive. The following tabulation tells the story (1).

\section{TABLB I}

Available Workers Who Whre Totally UNEMPIOYED OR ENGAGED IN EMERGENCY Work November 30, 1937, by AGE

\begin{tabular}{c|c|c}
\hline Age & $\begin{array}{c}\text { Estimated } \\
\text { Per Cent }\end{array}$ & $\begin{array}{c}\text { Estimated } \\
\text { Number }\end{array}$ \\
\hline $15-19$ & 41 & $1,934,000$ \\
$20-24$ & 24 & $1,989,000$ \\
$\ldots$ & $\ldots$ & $\ldots \ldots \ldots$ \\
$15-24$ & 30 & $3,923,000$ \\
$25-34$ & 16 & $2,225,000$ \\
$35-44$ & 16 & $1,839,000$ \\
$45-54$ & 17 & $1,576,000$ \\
$55-64$ & 20 & $1,029,000$ \\
$65-74$ & 19 & 349,000 \\
Aill Ages & 20 & $\ldots \ldots, \ldots 3,000$ \\
\hline
\end{tabular}

1 Includes 42,000 for whom age was not reported.

As the above table indicates, 41 per cent of the available workers between the ages of 15 and 19 were either totally unemployed or engaged in emergency work. In other words, unemployment took a toll greater by more than two and a half times in the age range 15 to 19 than in the age range 25 to 55 .

No one can accurately predict the extent of unemployment in the period following World War II, but whatever it is, it will undoubtedly strike the middle and late teens more heavily than any other age segment of the population (4).

In the second place, "'tween age" youth will face serious competition in the labor market because veterans have first claim on whatever jobs there are. They will return 
in huge numbers and stir the conscience of the nation. They will be thoroughly organized and if the history of veterans' organizations following other wars of the United States is any guide, they will exert political power in legislative halls beyond that wielded by any other pressure group. Already they have access to special subsidies for business, farming, education, and rehabilitation. No one will quarrel with these priorities. They are freely given by a grateful people. But the " 'tween age" will not be politically organized (they never have been), and they will have no subsidy. The NYA and the CCC no longer exist.

Competition for the novice in the occupational field will come from a third source. We refer to the displaced older workers of both sexes and the women workers of all ages who will probably not want to retire from the labor market in the numbers with which they entered it during the course of the war. Again, prediction in such matters is difficult, and an estimate of the numbers involved impossible to foretell with any degree of precision. But again if trends following World War I are any criterion, the recession of the tide of war workers will leave a number of employables in excess of that existing before 1940. Whatever their dimensions, these groups will have an advantage over the newcomers to the labor market. They will have work experience, occupational skills, seniority, and in large numbers the protection of the labor unions. At the same time, the "' 'tween age" will have limited or no work experience, limited or no occupational skills, little or no seniority, and few or no memberships in a protective union.

It is easy to grow sentimental about the plight of young people in the face of the situation outlined above, but the ungilded facts point to hard and sober times for young people entering the labor market following the war.

Some observers looking for a bright spot in this somber outlook predict that compulsory military training will relieve the pressure of youth on society. But this writer finds little relief in such a prospect. In the first place, we are not yet certain that the kind of preparedness required by a machine age will involve the training of large numbers of youth, and if it should, it will probably not include one half of the group, namely girls, and it will postpone but not solve the problem for the boys.

\section{The Counselor's Task}

What then is the upshot of this argument for the counselor of " "tween age" youth? Obviously his job will be baffling and tough, but he must attack it vigorously and with confidence. He must face realistically the highly competitive character of the labor market, but in working with young people he should sedulously avoid any hint that he regards them as members of a "lost generation." They are not "lost." Anyone acquainted with the temper of youth knows that because most of their life is ahead and because they are becoming sharply aware of their growing powers, youth are incurably hopeful about the future. The studies of the American Youth Commission confirm this fact for the pre-war period. Investigations by Boodish and Milligan find much optimism in the attitudes of wartime youth toward post-war jobs $(3,7)$.

But the counselor must help young people face frankly the transformation which the end of the war brings in their status. The counselor will need to remember that the male half of the generation which struggled through the depression of the nineteen thirties is now in the Armed Services and that the group of " 'tween age" youth who have become employable since 1940 have never known the sting of unemployment. On the contrary, the post 1940 group have been in great demand for parttime work during school and full-time work during vacation periods. In fact, the demands for their services have been so insistent and the pay so generous that they have in large numbers dropped out of school in advance of graduation. It will be difficult to persuade young people accustomed to high wages for low skilled service that their days of easy employment are numbered. But they should be warned emphatically not to count on their continuation. Counselors will employ various methods to drive this point home. In doing so, however, they may find support 
in the histories of young people tossed around by unemployment in the years before the war. In the face of an almost certain reversal of status, young people should also be advised to store away their earnings in these days of relative affluence in anticipation of the inevitable expense which the pursuit of an adequate educational program would entail. Every dollar saved now will mean more schooling later on. And to repeat a point already made-only the veterans will receive financial aid for education. The oncoming crop of youth will have to pay their own educational way.

\section{Stress Education}

The experience of the war, however, should provide the counselor with some effective material in advising young people about the importance of education. He can point to the weight attached to formal education by leaders of the Armed Services. For example, Ford ( 5 ) in 1943 reports a survey indicating that all but 6.5 per cent of a sample of 20,000 officer candidates in the Army had successfully completed twelve or more grades of education. And Havighurst and Russell (6) discovered after a substantial investigation that the "amount of schooling is a good predictor of rank in the Armed Services. In particular, high school graduation is almost essential for promotion to the level of commissioned officer .... Educational background appears to be one of the principal factors, if not the primary factor in promotion in the Armed Services" (p. 210).

The counselor can also cite the even greater role played by systematic instruction as a part of regular military training. He can, in addition, refer to the extensive programs for training within industry as a significant contribution to the production of war materials. But most important of all, he should emphasize the changes which the exigencies of combat will produce in the occupational pattern after the war. It can be safely predicted that these changes will not only create new kinds of work but will place a new and added accent on training for the many vocations in which people make a living.

There are many angles to the last point.
Young people who have come to the occupational scene since 1940 have not only known a wage scale which for them is not likely to continue, but they have also become vocationally wise in a period when the occupational pattern has been severely distorted. For example, the war has, for obvious reasons, given great prominence to nursing but will there be as great a demand for nurses in peace as there is in war, and if there is, will not the increased supply of nurses created by the war take care of any possible increase of nursing services in the years to come? If the implication of these questions is plausible, the counselor should resist any tendency to continue an indiscriminate campaign on behalf of nursing. The same argument applies to certain kinds of factory work which war production opened up for the first time in the occupational history of women. The reverse of this argument will have an important bearing on teaching and social welfare.

In many respects the war has given a serious setback to the profession of teaching. In many quarters the low estate of teaching has been an unmitigated scandal. The same is true of the welfare, recreational, and youth services. Again, the counselor must guard against the pull of the war away from the essential work of peace. He must be prepared to aid young people in restoring balanced attitudes toward civilian jobs. The same analysis applies to the fields of civilian aviation, communication, distribution, and a multitude of other areas, the elaboration of which is outside the province of this discussion.

The counselor must also redouble his efforts to keep abreast of the swift developments in new jobs and new training which the phenomenal technological progress of the war effort has created. Will the new ways of doing old work, and the new ways required by new work make new demands on the training programs of high schools and other institutions? Or will they call for a renewed emphasis on sound general education with on-the-job training for specific operations? Will these new ways of working have room for new-comers to the labor market with little or no relevant work experience? 
Know the Local. Labor Market

The answer to these and related questions will compel the progressive counselor to acquire an intimate and continuing knowledge of the local labor market. The war has profoundly disturbed practically every local labor market in the country. There are few factories in few communities which have not felt the impact of wartime conversion. In many cases this has meant the manufacture of a new product and in most cases has drained off workers from existing pre-war jobs creating an entirely new occupational distribution in the community. Readjustments are certain to occur in practically every local labor market in the country, and while the pre-war pattern may be a tentative guide to the postwar picture, no counselor worth his salt will dare trust the 1940 vintage of his occupational knowledge. His assurance can come only from a fresh, realistic, and ongoing inventory of the local labor market as it is and as it promises to be. National trends may serve as cues, but will not suffice. For in every case of wartime impact, modifications have occurred in particular installations, in particular communities-and young people are interested in specific jobs and not jobs in general.

From many fronts comes impressive evidence of the growing importance of occupa- tional counseling. Just now, concern for the veteran is uppermost. Next comes the war worker who must retool his skills for new operations. The writer hopes that this discussion has served to klieg-light the blind spot of present agitation for post-war counseling, namely, the needs of the oncoming generation of youth.

\section{BibLIOGRAPHY}

(1) A Program of Action for American Youth. Recommendations of the American Youth Commission. Washington: American Council on Education, 1943. Pp. 6.

(2) Bell, Howard M. Youtb Tell Their Story: A Study of the Conditions and Atritudes of Young People. Prepared for the American Youth Commission. Washington: American Council on Education, 1938. Pp. 273.

(3) Boodish, H. "Youth Thinks of the Future," Scbool Review, LI (November, 1943), 530-532.

(4) Davil, Paul T. Postwar Youth Employment. Prepared for the American Youth Commission. Washington: American Council on Education, 1943. Pp. 172.

(5) Ford, Haney. What You Should Know About the Army. New York: W. W. Norton and Co., Inc., 1943. Pp. 42.

(6) Havighurst, Robert J., and Russell, Mary. "Promotion in the Armed Services in Relation to School Attainment and Social Status," School Review, LIII (April, 1945), 202-211.

(7) Milligan, John P. "Youth Thinks about Postwar Employment," School Review, LIII (May, 1945). 265-272.

\title{
A County Plan for Counseling Veterans
}

\author{
FRANKLYN S. BARRY \\ Superintendent, Irondequoit Union School, District 3, Rochester, N. Y.; formerly Principal, Sidney \\ (N. Y.) Central School
}

$\mathrm{D}^{2}$ maware County, New York, has now in operation a County Plan for Returning War Veterans. It is a large, rural county with a population of 40,000 , of which approximately 3,600 are in the Armed Services. The county has no cities; only two of its villages have populations approximating 4,000 . The program for returning veterans operates through sixteen school districts (fifteen central schools and one union free school district). This insures a complete coverage for the county.

The plan was initiated in November, 1943, when Mr. Dreyfus, President of the County War Council, appointed four men to serve as Advisory Committee for Returning War Veterans. Letters were sent to more than 3,000 Delaware County men in the Armed 